\title{
Habitat alteration and community-level effects of an exotic mussel, Musculista senhousia
}

\author{
Jeffrey A. Crooks* \\ Scripps Institution of Oceanography, La Jolla, California 92093-0218, USA
}

\begin{abstract}
The mussel Musculista senhousia is capable of marked habitat alteration through the construction of byssal mats on the surface of soft sediments. Here I demonstrate the importance of this alteration on sedimentary properties and resident macrofaunal assemblages of a tidal flat in Mission Bay, San Diego, California, USA, where the mussel is exotic. In well-developed mats, percent fine sediments, percent combustible organic matter, and sediment shear strengths were increased relative to adjacent areas without mats. Comparisons of naturally occurring areas with and without mats of $M$. senhousia, as well as comparisons of the same tidal flat when mussels were seasonally present and absent, revealed that assemblages within mussel mats differ from those in sediments without mats. The primary effect of the mussel and its mats was facilitation of other organisms. Total densities of all macrofaunal individuals as well as species richness were typically higher inside than outside mussel mats. Two species that exhibited large enhancements of densities within mussel mats were the tanaid Leptochelia dubia and the gastropod Barleeia subtenuis. Oligochaetes, a numerically important component of the tidal flat, appear least facilitated by the presence of mats. A shortterm, manipulative experiment that examined the effects of mussel mat mimics on the colonization of macrofauna suggested that the presence of physical structure alone can produce several of the patterns observed in naturally occurring mussel mats. These results highlight that alteration of habitats is an important effect of exotic species, and that these habitat alterations can have subsequent effects on resident biotic communities.
\end{abstract}

KEY WORDS: Community structure Exotic species - Habitat alteration - Ecosystem engineering . Benthic macrofauna Facilitation. Musculista senhousia - Mission Bay

\section{INTRODUCTION}

Introduced species are known to influence invaded assemblages in many ways. Commonly considered mechanisms by which exotics affect other species include competition, predation, parasitism, and alterations of food webs or nutrient cycling (Vitousek 1990, Williamson 1996). Considered much less frequently are the effects of habitat-modifying species, or 'ecosystem engineers', on resident biota (e.g. Vitousek 1990, D'Antonio \& Dudley 1995, Williamson 1996, but see Simberloff 1981). This lack of recognition of exotic habitat modifiers reflects a general tendency to over-

•E-mail: jcrooks@ucsd.edu look the role of species in creating, destroying, or otherwise modifying habitats (Jones et al. 1994, Lawton 1994). In recent years, however, there has been an increased effort to better define the role of these species in ecosystems (Jones et al. 1997).

Estuarine ecosystems (including bays, lagoons, and true estuaries) provide ample opportunity to examine the effects of non-native organisms. They are among the most vulnerable of the world's ecosystems in terms of anthropogenic introductions (Carlton 1989), but relatively little is known about the effects of these nonnative species. Previous research on estuarine exotics has concentrated on identifying invaders and transport mechanisms (e.g. Carlton \& Geller 1993), autecology of invaders (e.g. Crooks 1996, Furota 1996a, b), and interspecific interactions such as competition (e.g. Race 
1982, Brenchley \& Carlton 1983) and predation (e.g Grosholz \& Ruiz 1995). Fewer studies have examined if and how estuarine exotics can alter the physical nature of ecosystems. However, there is limited evidence that resident assemblages can be changed by invasive ecosystem engineers, for example, through the construction of habitat by autotrophs (Posey 1988) or the destruction of habitat by herbivores (Bertness 1984).

Among the most successful invaders in marine and freshwater systems are bivalves in the families Mytilidae (sea mussels) and Dreissenidae (false mussels). Mussels have the potential to dramatically affect communities and ecosystems, as they are often dominant space occupiers, can alter habitats through construction of dense beds, and can link benthic and pelagic systems through filtration of the water column and deposition in the benthos (Suchanek 1985 , Seed \& Suchanek 1992 and references therein). Most of the research on the effects of mussels, however, has concentrated on native species. One notable exception to this is the zebra mussel Dreissena polymorpha in freshwaters (e.g. Nalepa \& Schloesser 1993). Other mussel invasions throughout the world include Mytilus galloprovincialis in Australia, South Africa, Japan, and California, USA (Seed 1992), Perna perna in Texas, USA (Hicks 1993), Perna viridis and Limnoperna fortunei kikuchii in Japan (Asakura 1992), and Brachidontes variabilis and Xenostrobus sp. in the Mediterranean (Safriel \& Sasson-Frostig 1988, Lazzari 1994). Some soft-sedimentdwelling, exotic mussels include the ribbed mussel Arcuatula demissa (or Geukensia demissa), a salt marsh species that has been introduced from the east coast of the United States to California (Carlton. 1979), and the Asian mussel Musculista senhousia, which has been introduced into Australia (Willan 1987), the Mediterranean (Hoenselaar \& Hoenselaar 1989), and the Pacific coast of North America (Kincaid 1947). $M$. senhousia typically weaves a byssal cocoon, and when it occurs in high densities these cocoons form a mat or carpet on the surface of the sediment (Morton 1974).

The objectives of this research were to document the effects of the exotic mussel Musculista senhousia (hereafter referred to as Musculista) on the soft-sediment intertidal habitat of Mission Bay, San Diego, California, and to determine the response of the resident macrofaunal community to these habitat changes. Faunal responses to the invasion of Musculista can be viewed on several spatial and temporal scales. In a broad context, Musculista is a relatively new invader in the system (approximately $30 \mathrm{yr}$; Crooks 1996), so observed interactions represent recent relationships that have not developed in a co-evolved community. On smaller scales, Musculista is patchy both in space and time; the mussel typically exists in patches of decimeters to meters and is only seasonally abundant on the tidal flat (Crooks 1996, unpubl. data). This small-scale spatio-temporal variability permitted the testing of the hypotheses that abiotic and biotic properties inside and outside naturally occurring mussel mats are indistinguishable. Potential causal factors giving rise to observed differences between natural mussel-mat and no-mat communities were then explored with a manipulative experiment that tested the effects of addition of physical structure (i.e. mussel mat mimics) on macrofaunal communities.

\section{METHODS}

Study area. The research was carried out in the Northern Wildlife Preserve in the northeast corner of Mission Bay, San Diego, where remnant salt marsh (Spartina foliosa and Salicornia spp.), sand/mud flat, and eelgrass (Zostera marina) habitats are present. Mission Bay is a shallow, highly-modified system (through filling and dredging), and its salinity is usually near full seawater. The temperature of the bay generally ranges between 1.2 and $26^{\circ} \mathrm{C}$ (Levin 1983). The mats created by adult Musculista are often conspicuous elements of the sandy-mud intertidal landscape (Fig 1), and it is possible to visually identify areas with and without high densities of adult mussels.

Musculista senhousia. Musculista was first found on the U.S. Pacific coast in Puget Sound in the 1920s, where it was accidentally introduced with the Japanese oyster Crassostrea gigas (Kincaid 1947). In the 1940s, the mussel appeared in San Francisco Bay (Carlton 1979), and in the mid-1960s it was first found in Mission Bay in southern California (MacDonald 1969), where it was probably introduced via ballast water or ship fouling (Cohen \& Carlton 1995). By the mid-1980s, the mussel was one of the most common members of intertidal and subtidal soft-bottom communities of both San Diego Bay and Mission Bay (Crooks 1992). Musculista possesses many opportunistic characteristics: it is small (maximum length of about $3.5 \mathrm{~cm}$ ), short-lived (most are annuals but some live up to $2 \mathrm{yr}$ ), experiences high mortality, attains very high densities, grows quickly, and has high fecundity (Tanaka \& Kikuchi 1978, Crooks 1996).

Field sampling and laboratory procedures. Sediments and associated organisms (including Musculista) were collected quarterly from July 1993 to October 1996 from a site $(20 \times 5 \mathrm{~m})$ established on a sandy-mud tidal flat at approximately $0.33 \mathrm{~m}$ above MLLW (Mean Lower Low Water). On each sampling date, 6 stations were chosen at the site. Different stations were sampled on each date. Within each station, 
paired samples were collected approximately $0.5 \mathrm{~m}$ apart. The nature of the sampling varied according to the condutions present on the tidal flat. If mussel mats were visually present (July 1993, October 1993 July 1994, October 1995, and July 1996), the stations were chosen so that each contauned patches with and without mussel mats. Within each station, a sample was taken from the mat area (sample a) and another sample was taken ca $0.5 \mathrm{~m}$ away in a nomat area (sample b). In general, it was relatively easy to accurately determine areas with and without mussels. On 2 occasions (July 1994 and October 1995), however, one of the no-mat samples in fact contaned a relatively large number of mussels lover 8 times that of the average of the other no-mat samples) that were not observed during sampling but that were evident during processing of samples. These samples and their corresponding pair from the mat area in the station were eliminated from further analyses.

On sampling dates without obvious mussel mats (April 1994, January 1995, Aprll 1996. and October 1996), the 6 stations at the site were randomly selected and each of the paired sets of samples within the station came from areas approximately $0.5 \mathrm{~m}$ apart, with samples arbitrarily designated a and b. One sample in April 1996 was lost, so both samples from that station were not considered in the analysis. Samples from other quarterly sampling dates are not considered here because conditions on the tidal flat (e.g macroalgal blooms) did not permit sampling of either mat/no-mat or no-mat/no-mat sediments.

For characterization of macrofaunal communities, cores with a surface area of $0.001 \mathrm{~m}^{2}$ were taken to a depth of $2 \mathrm{~cm}$ (preliminary studies demonstrated that over $90 \%$ of the animals on the tidal flat occurred within the top $2 \mathrm{~cm}$ ). These cores were preserved unsieved in $10 \%$ buffered formalin, and later sleved through $300 \mu \mathrm{m}$ mesh in the laboratory. All materlal retained on the sieve was sorted under a dissectıng microscope and all macrofauna were counted and identified to the lowest taxonomic level possible (usually species) and then transferred to $70 \%$ alcohol. Mussel lengths were measured by ocular micrometer or digital caliper, and these were used to calculate dry flesh weight of the mussels according to the length-weight relationships defined for Mission Bay Musculista (Crooks 1996).

A
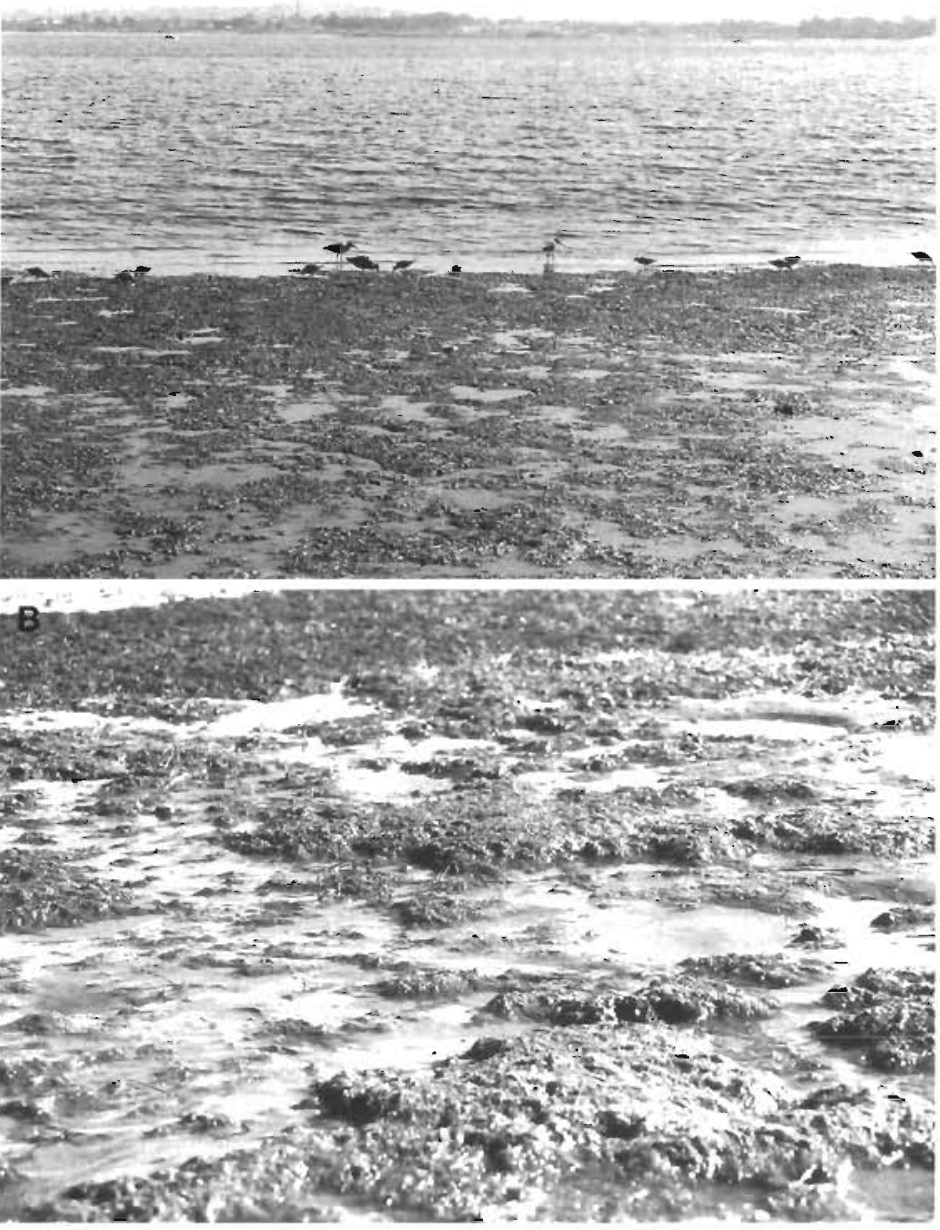

Fig 1 (A) Patchy mats (raised areas) of Musculssta senhousid in the Northern Wildlife Preserve, Mission Bay, San Diego, Callfornia, USA (B) Close-up of mussel mats (width of area in foreground is approximately $3 \mathrm{~m}$ )

Information for each species regarding feeding strategy and larval development mode was obtained from the literature (Fauchald \& Jumars 1979, Morris et al. 1980, Wilson 1991). Anımals with known larval development modes were categorized as having either planktonic (both planktotrophic and lecithotrophic) larvae or direct development. The anmals also were categorized by feeding modes as surface feeders (nncluding surface-deposit feeders, suspension feeders, and macrophages) or subsurface feeders (see Appendix 1).

Sedimentary analyses were performed on 3 dates (October 1993, July 1994, and October 1995) with mat/no-mat comparisons Cores $\left(0.001 \mathrm{~m}^{2}\right)$ were taken to a depth of $6 \mathrm{~cm}$, and on 2 dates (July 1994 and October 1995) these were split into $0-2$ and $2-6 \mathrm{~cm}$ fractions. The sediment was then frozen for later analysıs. Sediment particle size ( $\%$ weight of sand vs \% weight 
of silts and clays) was determined by wet-sieving thawed sediment through a $63 \mu$ m screen, drying the $<63 \mu \mathrm{m}$ and $>63 \mu \mathrm{m}$ fractions overnight at $60^{\circ} \mathrm{C}$, and then weighing them. Percent organic matter was determined by combusting pre-weighed sediment $(<1 \mathrm{~mm})$ in a muffle furnace at $550^{\circ} \mathrm{C}$ for $24 \mathrm{~h}$. The sediments used for both analyses were initially sieved through a $1 \mathrm{~mm}$ mesh to remove large material, primarily shells and large eelgrass and algal fragments. Shear strengths of sediments (to a depth of $\mathrm{ca} 1 \mathrm{~cm}$ ) within well-developed mussels mats and adjacent no-mat areas were measured in situ (August 1996) with a Torvane shear device.

Experimental test of effects of physical structure. In order to examine the hypothesis that mussel effects on macrofaunal colonization derive primarily from the physical structure of the mussel mats, an experiment was conducted in April 1997. Ten blocks on the tidal flat were established, and within each block 2 circular areas $\left(0.0625 \mathrm{~m}^{2}\right)$ were cleared of sediment to a depth of approximately $4 \mathrm{~cm}$. Each excavated plot was then filled to the level of the surrounding sediment with high intertidal beach sand (containing no macrofauna), and 1 of 2 treatments was then randomly assigned to each plot. The 2 treatments consisted of (1) a mussel mat mimic (furnace filter material consisting of plasticcovered plant matter) held in place with buried plastic stakes, and (2) no mat mimic (a control). After $2 \mathrm{wk}$, cores $\left(0.001 \mathrm{~m}^{2}\right.$ and $4 \mathrm{~cm}$ deep) were taken from each plot to examine recruiting and migrating macrofauna. Only 6 of the blocks were sampled, because mats at the other plots had been disturbed and/or removed (probably by gulls). The samples were preserved in formalin, later sieved through $300 \mu \mathrm{m}$ mesh, and all macrofauna were identified to the lowest taxonomic level possible.

Analyses. Statistical differences in means within each date in the mensurative and manipulative experiments were tested using paired t-tests $15 \mathrm{df}$ for all dates except July 1994, October 1995, and April 1996, with $4 \mathrm{df}$ each). Differences in means between mat samples and adjacent no-mat samples averaged across dates were tested using Randomized Complete Block ANOVAs, with date as a blocking factor. In this analysis, the average of values from July 1993 and October 1993 was used, because these represent the only 2 consecutive sampling dates when mats were present. On all other sampling dates, mat presence and absence alternated. Comparisons of fauna at times when mats were present to times when mats were absent were made using ANOVA. All non-percentage data were $\log (x+1)$ transformed prior to analysis in order to aid in homogenizing variances and to evaluate relative rather than absolute differences in paired samples (Mead 1988). All percentage data were arcsine square-root transformed prior to analyses. Unless otherwise stated, all data are back-transformed means and standard errors (resulting in errors that are asymmetric about the mean). No attempt has been made to control experiment-wise error rates (Mead 1988, Stewart-Oaten 1995), and p-values below 0.05 were considered significant. Musculista counts were removed from total densities for all calculations and statistics involving macrofauna.

For comparisons of macrofaunal assemblages both within and among stations on each sampling date, percentage similarities (Krebs 1989) were calculated using the formula:

$$
\mathrm{PS}=\sum_{i=1}^{n} \operatorname{minimum}\left(p_{\mathrm{a} i}, p_{\mathrm{b} i}\right)
$$

where PS = percentage similarity between the 2 samples, $p_{\mathrm{a} i}=$ percentage of species $i$ in sample $\mathrm{a}_{1} p_{\mathrm{b}_{3}}=$ percentage of species $i$ in sample $b$, and $n$ is the number of species in samples a and/or $b$. Three sets of percentage similarities were calculated for each sampling date. First, each within-station pair of samples (a vs b) was compared. In addition, 2 among-site comparisons were made: (1) each sample a with other a samples, and (2) each sample b with other b samples.

For analyses of species diversity patterns, species richness was determined using the rarefaction method (Hurlbert 1971).

\section{RESULTS}

\section{Musculista occurrence}

Musculista was seasonally abundant on the tidal flat (Fig. 2), with highest abundances and the presence of recognizable mats typically occurring in the summer and fall. There was, however, variation in the timing and intensity of recruitment, as is indicated by the size structure, densities, and biomass of Musculista (Fig 2). For example, in July 1994, the mussels were smaller and the biomass less than in other months with mats, suggesting that these mats were younger than those observed at other times. Following the 1993 and 1994 recruitment events, mussel mats persisted throughout the fall, but were not evident in either January 1994 (author's pers, obs.) or 1995 (Fig. 2). In January 1996, however, well-developed mats were present on the tidal flat, remaining from a very heavy recruitment of mussels the previous spring (author's pers. obs.). A few large mussels also persisted into April 1996, although these did not form obvious mats (Fig. 2). The recruitment event of 1996 appeared to be relatively weak, and the mats that were present in July had disappeared by October (Fig. 2). 
Fig. 2. Musculista senhousia. Sizerelative frequency $(\%)$ distributions (for samples $\mathrm{a}$ and $\mathrm{b}$ combined). Also provided are untransformed mean numbers of individuals $( \pm \mathrm{SE})$ and mean biomasses (mg dry flesh weight \pm SE) per core $\left(0.001 \mathrm{~m}^{2}\right)$

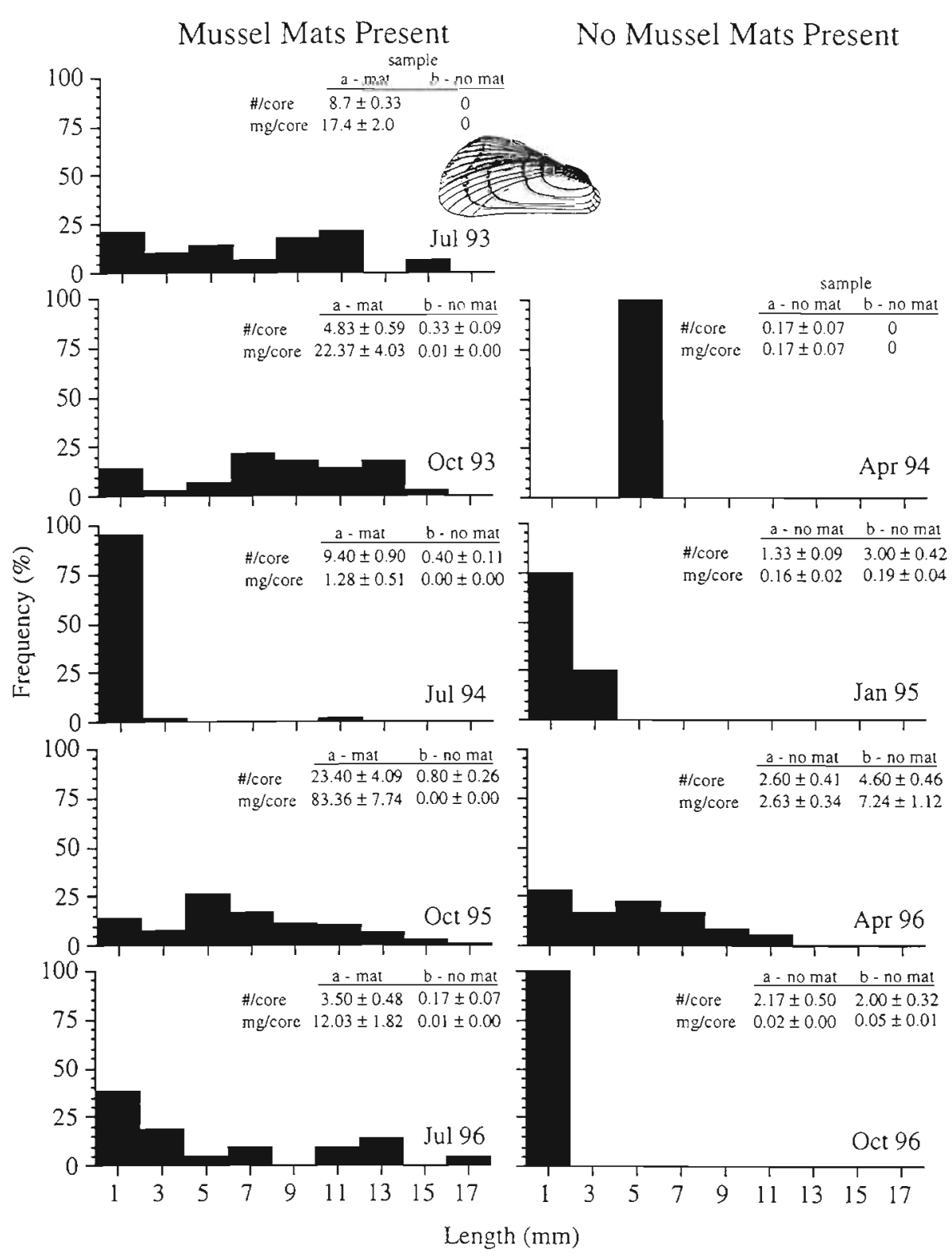

Table 1. Sediment properties (percent silts/clays and percent combustible organic matter) on 3 dates with mat/no-mat comparisons. Values are back-transformed means for the $0-2$ and $0-6 \mathrm{~cm}$ depth fractions, and numbers in parentheses represent the range for the mean $\pm 1 \mathrm{SE}$. $p$-values are from paired $t$-tests $(\mathrm{df}=4$, except in October 93 when $\mathrm{df}=5)$, and bold-faced values equal $\mathrm{p}<0.05$. na: not analyzed; "poorly-developed mat; " well-developed mat

\begin{tabular}{|c|c|c|c|c|c|c|}
\hline \multirow{2}{*}{ Date } & \multicolumn{3}{|c|}{$-0-2 \mathrm{~cm}$} & \multicolumn{3}{|c|}{$-0-6 \mathrm{~cm}$} \\
\hline & Mat & No mat & $p$-value & Mat & No mat & p-value \\
\hline \multicolumn{7}{|c|}{ Silts/clays (\%) } \\
\hline Oct $93^{\prime} \cdot$ & na & na & na & $15.5(13.6-17.4)$ & $9.6(8.3-10.7)$ & 0.013 \\
\hline Jul $94^{\circ}$ & $9.4(8.4-10.5)$ & $10.4(8.6-12.3)$ & 0.452 & $10.4(10.0-10.7)$ & $16.3(12.5-20.4)$ & 0.334 \\
\hline Oct $95^{*}$ & $19.7(16.4-23.2)$ & $8.1(6.5-9.9)$ & 0.026 & $12.8(11.7-14.0)$ & $8.1(7.7-8.5)$ & 0.033 \\
\hline \multicolumn{7}{|c|}{ Organic matter $(\%)$} \\
\hline Oct $93 \cdots$ & na & na & na & $1.72(1.58-1.87)$ & $1.13(1.04-1.22)$ & 0.004 \\
\hline Jul $94^{\circ}$ & $0.96(0.82-1.12)$ & $1.33(1.01-1.68)$ & 0.251 & $1.16(1.06-1.27)$ & $1.11(1.04-1.19)$ & 0.721 \\
\hline Oct $95 \cdots$ & $0.69(0.60-0.78)$ & $0.35(0.26-0.45)$ & 0.015 & $0.70(0.66-0.77)$ & $0.55(0.49-0.65)$ & 0.058 \\
\hline
\end{tabular}




\section{Alteration of the benthic habitat by Musculista}

Through its construction of byssal mats, Musculista is capable of changing the physical nature of the sediment (Fig. 1). Generally, mats consisted of relatively large amounts of mussels, living and dead macroalgae, eelgrass and shell fragments, byssal threads, sediments, and associated biota. Living mussels were usually the largest structures within the mats. Mats were typicaliy raised several centimeters relative to areas without mats, and this mat construction can stabilize the sediment surface. Shear strength measurements (August 1996) were $70 \%$ greater in mats $\left(0.48 \mathrm{~kg} \mathrm{~m}^{-2} \pm 0.026, \mathrm{n}=12\right)$ than in mat-free sediments $\left(0.28 \mathrm{~kg} \mathrm{~m}^{-2} \pm 0.016, \mathrm{n}=12 ; t_{11}>4.5, \mathrm{p}<\right.$ $0.001)$. However, the mussel mats are transient features on the tidal flat. Shells of the dead mussels (which tend to break apart quickly) or remains of uninhabited byssal cocoons were rare on the tidal flat (author's pers. obs.).

Sedimentary properties within well-developed mussel mats, present in October 1993 and October 1995 (Fig. 2), differed from those in areas without mats (Table 1). In October 1995, sediment within mats had significantly higher percentages of silts/clays (for both the $0-2$ and $0-6 \mathrm{~cm}$ fractions) and percent organic matter (for the $0-2 \mathrm{~cm}$ fraction) than mat-free sediments. In October 1993, the amount of fine sediments and organic matter in the $0-6 \mathrm{~cm}$ fraction was greater than in adjacent no-mat areas. In July 1994, when mats contained smaller mussels and less biomass (Fig. 2), there were no significant differences in percent fines or combustible organic matter between mat and no-mat areas. In October 1995, potential effects of the mussels on grain sizes and organic matter were limited to the surface of the sediment. When significant differences existed in the $0-2 \mathrm{~cm}$ fractions for grain size and organic matter and in the $0-6 \mathrm{~cm}$ fraction for grain size (Table 1), no significant differences were found for the 2-6 fractions (not shown) for either organic matter $\left(t_{5}=0.47, \mathrm{p}=0.663\right)$ or grain size $\left(t_{5}=0.30, p=0.777\right)$.

\section{Macrofaunal density}

Total macrofaunal densities (excluding Musculista; Fig. 3A, B) ranged from a low of 30 ind. $0.001 \mathrm{~m}^{-2}$ (outside mussel mats in July 1993) to 277 ind. $0.001 \mathrm{~m}^{-2}$ (inside mussel mats in October 1993). Averaged across all dates with mat/no-mat comparisons, 2.7 times more indi- viduals were found within mats than in adjacent sediments without mats $\left(F_{1,3}=17.7, p=0.025\right)$. Macrofaunal densities were significantly higher in mats during 4 of the 5 mo with mat/no-mat comparisons (Fig 3A). In months without mats, no significant differences in macrofaunal densities between $a$ and $b$ samples existed (Fig. 3B).

Most major taxonomic groups exhibited increased densities within mussel mats relative to mat-free sediments (Fig. 4). On all 5 dates, crustaceans (primarily tanaids and amphipods) were significantly more abundant within mats. Insect (midge) larvae were significantly more abundant on 3 dates. Molluscs (primarily Barleeia subtenuis) and polychaetes (including Exogene cf. lourej, Capitella sp., and Schistomeringos rudolphi) were significantly more abundant within mats on 1 date each. Oligochaete densities appeared to be more comparable in mat and no-mat areas, as they only experienced significantly increased densities within mats on 1 date, and this difference was rela-

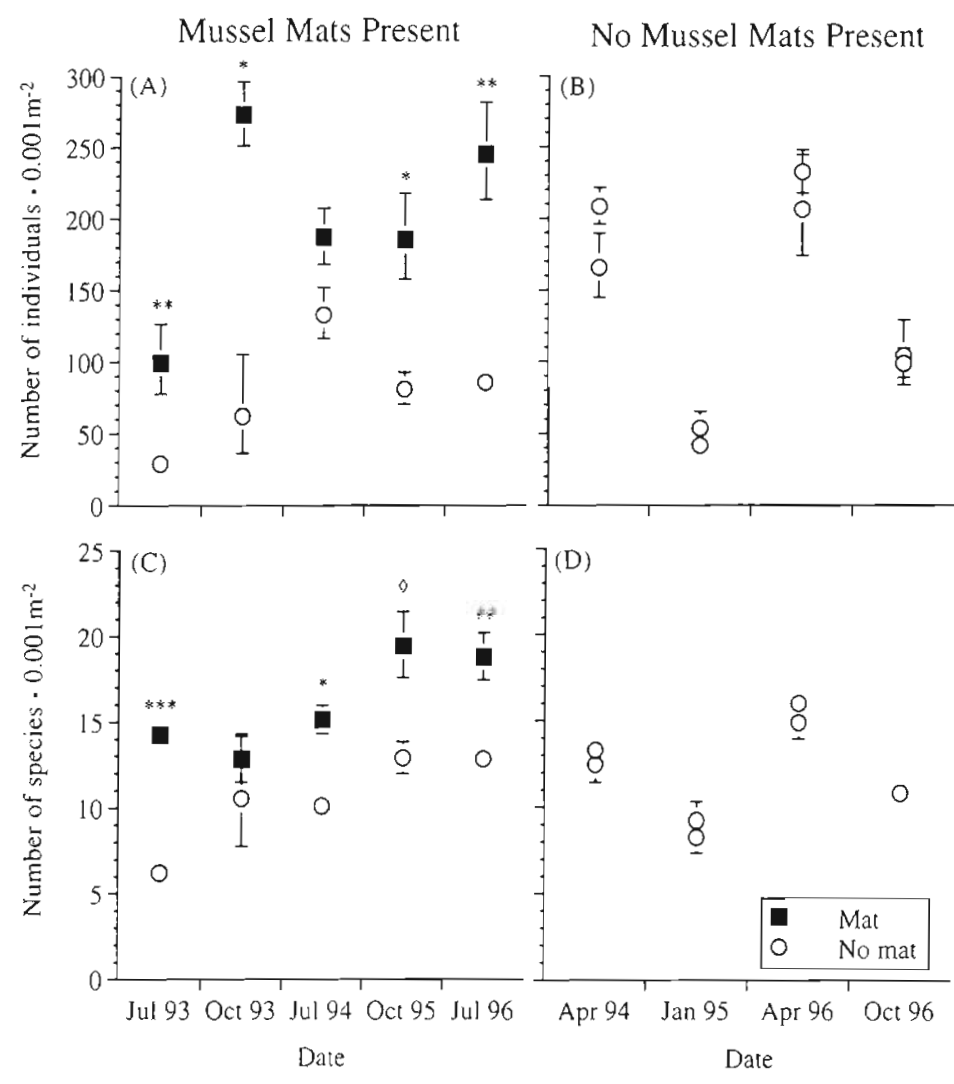

Fig. 3. Total macrofaunal densities and species richness on the tidal flat Data are mean numbers $0.001 \mathrm{~m}^{-2} \pm \mathrm{SE}(\mathrm{n}=6$ except in July 94 , October 95, and April 96, when $\mathrm{n}=5$ ). (A, B) Total densities of macrofauna (excluding Musculista senhousia) when mats were present and absent, and (C, D) numbers of species when mats were present and absent. Data for each date are from sets of paired samples taken approximately $0.5 \mathrm{~m}$ apart (see text for more details). $\cdots p<0.001, \cdots p<0.01, p<0.05$, ${ }^{\circ} \mathrm{p}<0.1_{i}$ no symbol: $\mathrm{p}>0.1$ 


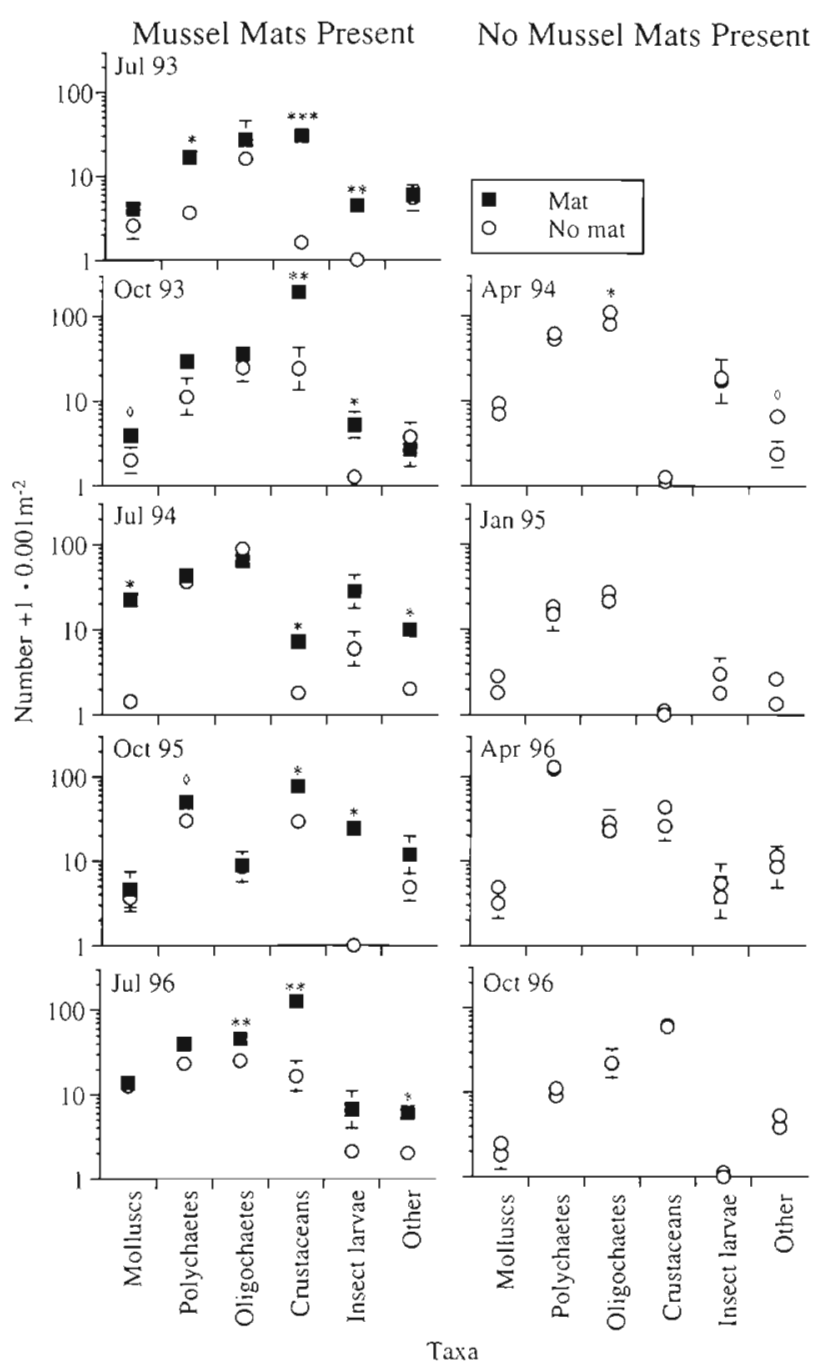

Fig. 4. Densities of major macrofaunal taxa. Data are mean numbers $0.001 \mathrm{~m}^{-2}(+1) \pm \mathrm{SE}$ ( $\mathrm{n}=6$ except in July 94 , October 95, and April 96, when $n=5$ ). The category 'other' includes cnidarians, turbellarians, nemerteans, and holothurians. $\cdots p<0.001, \cdots p<0.01, " p<0.05,{ }^{\circ} p<0.1$; no symbol: $p>0.1$

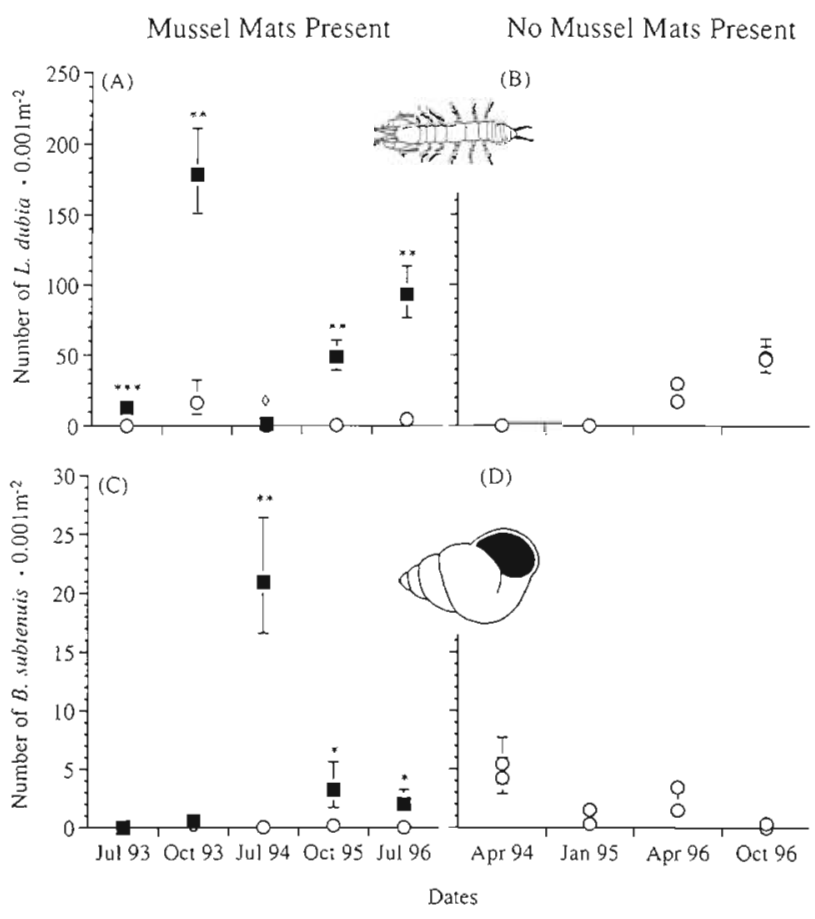

Fig. 5. Densities of 2 macrofaunal species. Data are mean numbers $0.001 \mathrm{~m}^{-2} \pm \mathrm{SE}(\mathrm{n}=6$ except in July 94 , October 95 , and April 96, when $\mathrm{n}=5$ ). $(\mathrm{A}, \mathrm{B})$ Densities of the tanaid Leptochelia dubia when Musculista senhousia mats were present and absent on the tidal flat, and (C, D) densities of the gastropod Barleela subtenuis when mats were present and absent. $\cdots p<0.001, \cdots p<0.01, p<0.05{ }^{\circ} p<0.1 ;$ no symbol: $p>0.1$

tively small (Fig. 4). In terms of percent representation (averaged across dates), oligochaetes were the only taxon that showed a significant difference, comprising $15 \%$ of the individuals within mats and $34 \%$ of the individuals in no-mat areas $\left(t_{3}=4.78, \mathrm{p}=0.017\right.$ ).

In months with no mussel mats, there was only 1 significant difference (oligochaetes in April 1994) in the 24 comparisons of abundances between the a and $b$ samples (Fig. 4). This is in accord with the prediction that the means of the samples should be equal given random sampling and that approximately 1 in every 20 comparisons will be significant at $\alpha=0.05$.

The increase in density of major taxonomic groups (Fig. 4) reflects a general increase in abundance of many species (and higher taxa) within mats (Table 2). On all 5 dates with mat/no-mat comparisons, more species had higher abundances inside than outside mats, and this difference was significant on 3 dates. Averaged across months, 4.1 times as many species were more abundant inside than outside mats $\left(F_{1,3}=19.7, \mathrm{p}=0.016\right)$. 


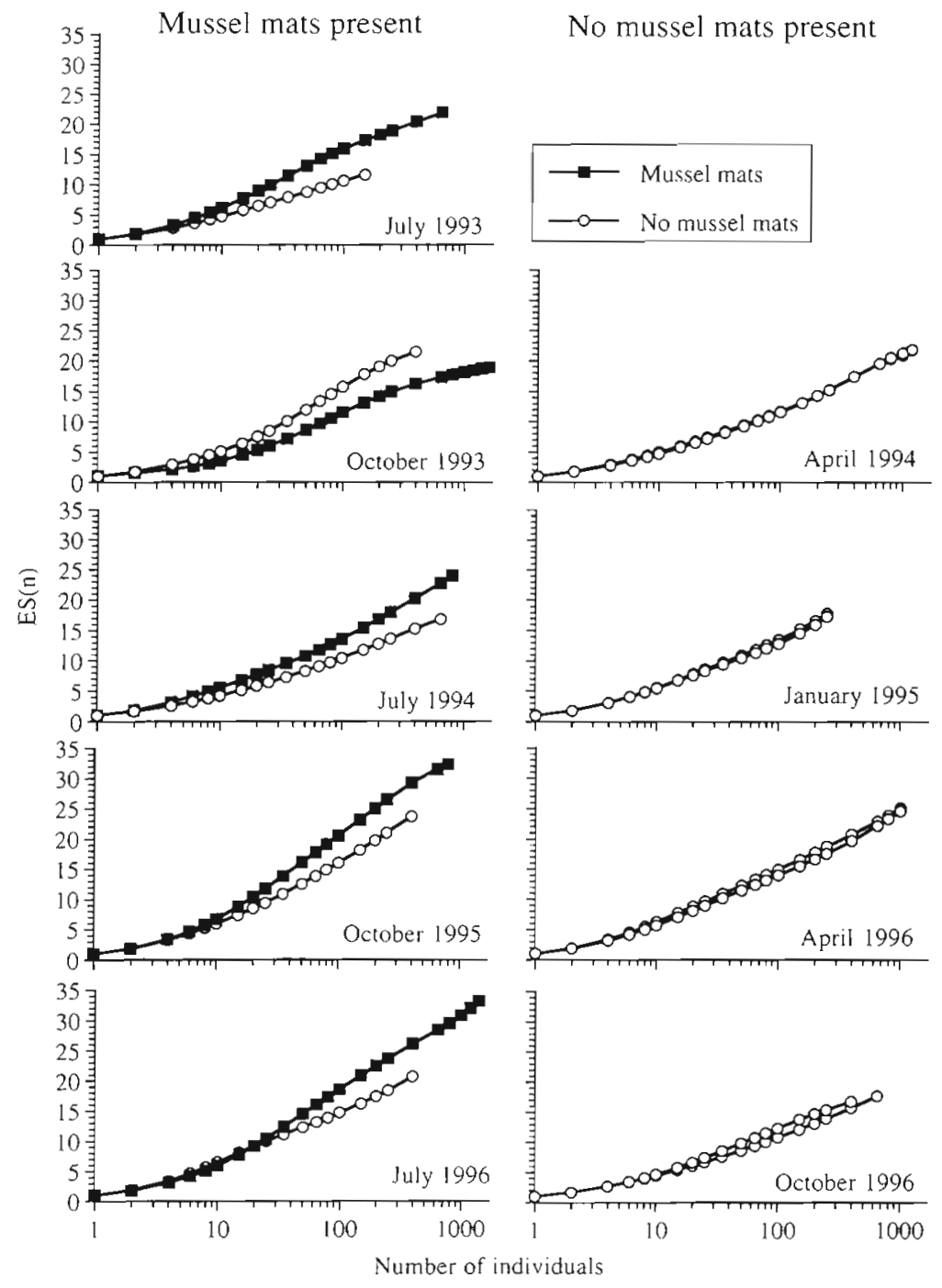

Fig. 6. Rarefaction curves plotting expected number of species within and outside of Musculista senhousia mats as a function of number of individuals [ES(n)] for each sampling date. Note log scale on $x$-axis

Mats of Musculista appeared to enhance densities of several species, while no single species had increased densities in no-mat areas (Appendix 1). Mats appeared to benefit 2 species in particular. The tanaid Leptochelia dubia was significantly more abundant within mats on 4 of 5 dates (Fig. 5A, B). In October of 1993, this species achieved the highest density of any species observed during the course of the study, with a density in mats of 190 ind. $0.001 \mathrm{~m}^{-2}$. The small gastropod Barleeia subtenuis was significantly more abundant within mats on 3 dates (Fig. 5C, D). The largest difference was in July 1994, when the snail's density was 30 times greater within mats.

\section{Species richness}

The number of species (i.e. species richness) per core (Fig. 3C, D) was greater inside mussel mats than in adjacent, mat-free sediments, with an average of 1.6 times as many species within mats $\left(F_{1,3}=277.3, \mathrm{p}<0.001\right)$. Species richness was significantly higher within mats on 3 dates (July 1993, July 1994, and July 1996; Fig. 3C). No significant differences existed in months without mats (Fig. 3D)

Species richness per number of individuals (from rarefaction estimates) also differed between mat and no-mat areas (Fig. 6). Mat/no-mat rarefaction curves during months with mussel mats were consistently less similar than the no-mat/ no-mat curves during months without mats. On 4 of the 5 dates with mat/no-mat comparisons, within-mat rarefaction curves were higher than no-mat curves (Fig. 6). On the one date (October 1993) where the mat curve fell below the no-mat curve, the average number of species per core also was not significantly higher within mats (Fig. 3C). However, this was the date with the greatest differences in total macrofaunal densities (Fig. 3A), due largely to the abundance of the tanaid Leptochelia dubia (Fig. 5A)

\section{Macrofaunal community similarities}

Mussel mats increased the small-scale spatial heterogeneity of macrofaunal community composition on the tidal flat (Table 3). The similarities of assemblages in within-station, paired cores ( $\mathrm{a}$ vs b) from months with mats (i.e. mat/no-mat comparisons) were significantly lower than the similarities of within-station,

Table 3. Similarities (Eq. 1) of macrofaunal communities (excluding Musculista senhousia) for months with mat/no-mat comparisons and months with no-mat/no-mat comparisons. Similarities were calculated for the paired samples within a station (a vs b) as well as for samples between stations ( $a$ vs a and $b$ vs b). Values are averages $( \pm S E, n=4$ ) across dates

\begin{tabular}{|c|c|c|c|}
\hline & \multirow{2}{*}{$\begin{array}{c}\text { Within-station } \\
\text { a vs b }\end{array}$} & \multicolumn{2}{|c|}{ Between stations } \\
\hline & & a vs a & $b$ vs $b$ \\
\hline $\begin{array}{l}\text { Mats present } \\
\left(a=\text { mat }_{i} b=\text { no mat }\right)\end{array}$ & $43.4( \pm 6.2)$ & $61.6( \pm 5.7)$ & $59.9( \pm 4.2)$ \\
\hline $\begin{array}{l}\text { Mats absent } \\
\text { ( } a=\text { no mat } b=\text { no mat })\end{array}$ & $71.2( \pm 3.1)$ & $64.4( \pm 3.9)$ & $63.4\{ \pm 6.4\}$ \\
\hline
\end{tabular}




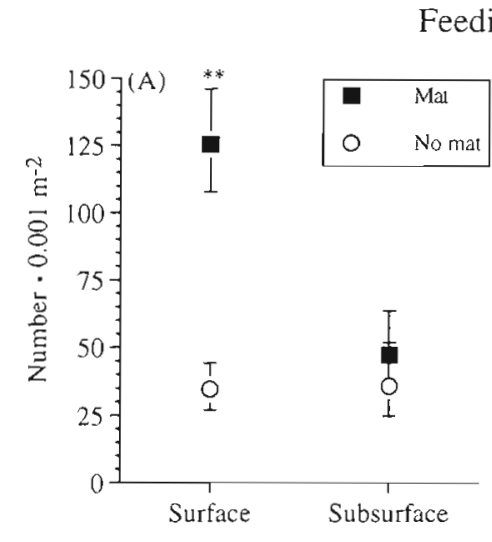

Feeding Modes

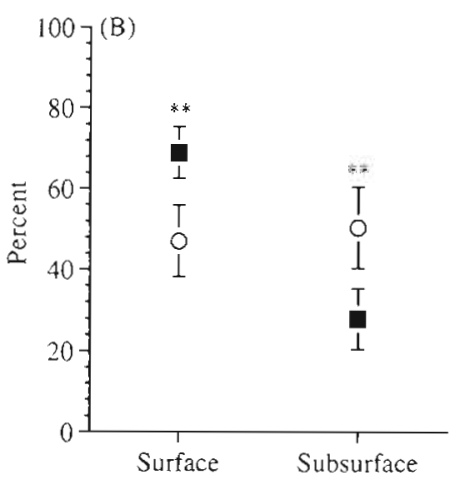

Larval Development Modes
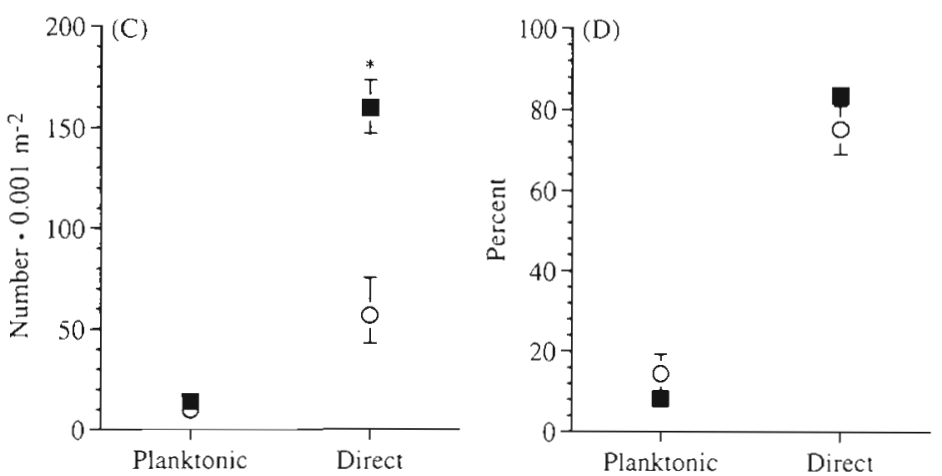

Fig. 7. Abundance and proportion of macrofauna exhibiting different feeding and development modes in Musculista senhousia mat and nomat areas, averaged across months when mats were present. Panels are comparisons of $(\mathrm{A})$ absolute densities (mean number $0.001 \mathrm{~m}^{-2} \pm \mathrm{SE}, \mathrm{n}=$ 4 ) and $(B)$ relative proportions (mean percentage $\pm 1 S E, n=4$ ) of different feeding modes, and comparisons of $(C)$ absolute densities (mean number $0.001 \mathrm{~m}^{-2} \pm \mathrm{SE}, \mathrm{n}=4$ ) and (D) relative proportions (mean percentage $\pm 1 \mathrm{SE}, \mathrm{n}=4$ ) of different larval development modes. ${ }^{*} \mathrm{p}<0.01$, p $p<0.05 ;$ no symbol: $p>0.1$ paired cores (a vs b) from months with no mats (i.e. no-mat/no-mat comparisons; $t_{6}=$ $4.2, p=0.006$ ). When mussel mats were present, the similarity of mat/no-mat pairs from within a station was lower than the comparisons of mat samples to other mat samples and the comparisons of no-mat samples to other no-mat samples $\left(F_{2, \bar{\sigma}}=12.0, \mathrm{p}=0.008\right)$. When mats were absent, however, the similarities of paired cores were not significantly different from the similarities of cores taken from different stations $\left(F_{2,6}=3.26, p=0.110\right)$. Thus, mats appear to alter the spatial structure of the tidal flat on approximately one-half meter scales. When no mats were present, randomly selected areas $0.5 \mathrm{~m}$ away tended to be the most similar to each other, whereas when mats were present, mat and no-mat areas $0.5 \mathrm{~m}$ away tended to be the least similar.

\section{Life habits}

The representation of macrofaunal feeding modes within mats differed from that in nomat areas (Fig. 7A, B). Surface feeders were significantly more abundant in mat than in no-mat samples (Fig. 7A), No significant difference existed between density of subsurface feeders in mat and no-mat areas. In terms of percent composition, subsurface feeders were relatively more abundant in nomat samples while surface feeders were more abundant in mat samples (Fig. 7B).

Table 4. Results of 2-week Musculista senhousia mat-mimic experiment. Values are back-transformed means per core $\left(0.001 \mathrm{~m}^{2}\right)$, and numbers in parentheses represent the range for the mean $\pm 1 \mathrm{SE}$. p-values are from paired t-tests (5 df), and bold-faced values represent $p<0.05$. The number of dates with significant differences between natural mat and no-mat areas (out of 5 total) are also given

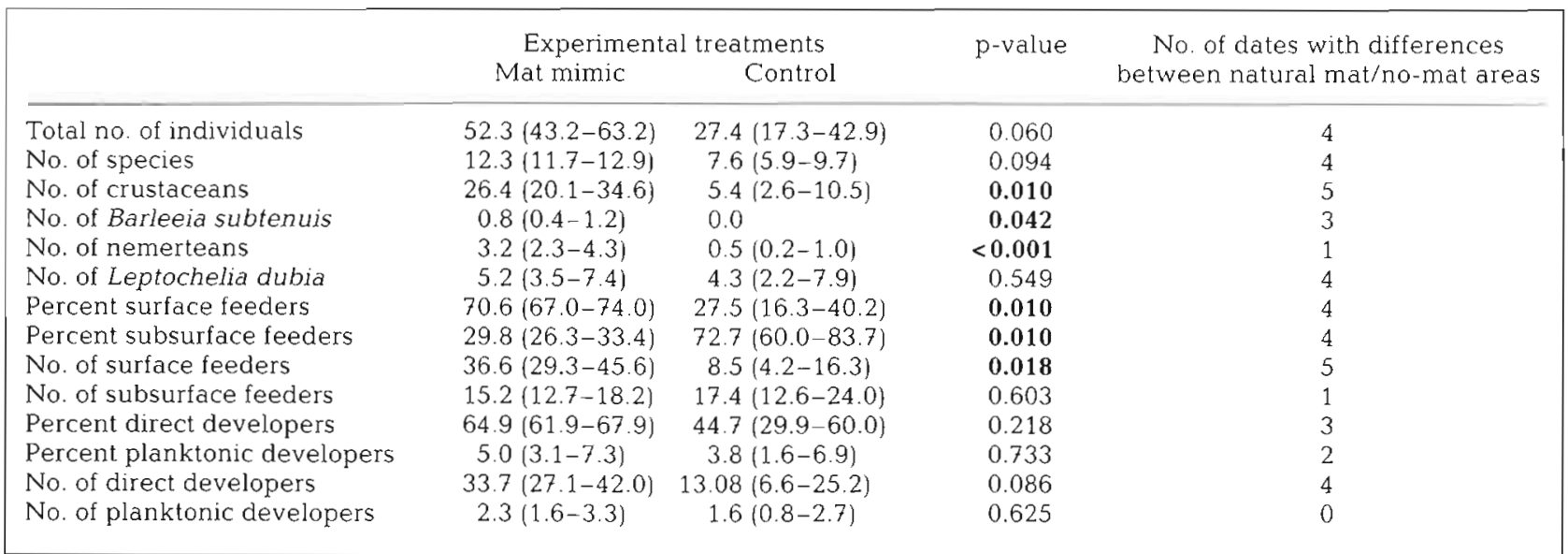


Direct developers had significantly higher densities inside than outside mats (Fig 7C). No significant differences existed for the densities or percent representation of planktonic developers or for the percent representation of direct developers (Fig. $7 \mathrm{C}, \mathrm{D}$ ).

\section{Experimental test of mat-mimic effects}

Results of the 2 wk mat-mimic experiment support the hypothesis that the presence of physical structure associated with mussel mats may facilitate some macrofauna. A number of the patterns characteristic of the natural mats were observed in the mat mimics (Table 4). Crustaceans (primarily gammarid amphipods), which as a group always had higher densities in the natural mussel mats than in mat-free sediments (Fig. 4), were also significantly more abundant within the mat-mimic treatment. The small gastropod Barleeia subtenuis, which was significantly more abundant within natural mats on 3 dates (Fig. 5C), was significantly more abundant within mat-mimic treatments, even though abundances were relatively low. Nemerteans were also found in significantly higher abundances within the mat-mimic treatment. Although differences were not significant, densities of macrofauna (per core) were almost twice as high in the presence of mat mimics than in control areas, and species richness was approximately 1.5 times greater. The tanaid (Leptochelia dubia), which was very abundant in natural mats (Fig. 5A), was no more abundant in the mat mimics than in the controls. However, tanaid densities were relatively low in the experimental treatments, and April may be a time of low abundance for the species (Fig. 5B).

Differences in the feeding modes of macrofauna found in plots with and without mat mimics (Table 4) resembled differences found in natural mat and no-mat areas (Fig. 7A, B). The percent representation of surface feeders, as well as their absolute densities, were significantly higher within the mat-mimic treatments. Conversely, subsurface feeders were proportionately more abundant within the control treatment. No significant differences were found for densities or percent representation of larval development modes in mat-mimic and control treatments, although 2.5 times more direct developers were found in mat-mimic than in control treatments (Table 4). In natural mat/no-mat comparisons, averaged across dates (Fig. 7C, D), the only significant difference was for densities of direct developers.

Table 5. Reported interactions of soft-sediment-dwelling mussels with benthic fauna. b: bivalve; c: crab; g: gastropod; p: polychaete; t: tanaid; sf: suspension feeder; df: deposit feeder

\begin{tabular}{|c|c|c|c|c|}
\hline Species & Inhibited fauna & Facilitated fauna & Comments & Source \\
\hline $\begin{array}{l}\text { Musculista } \\
\text { senhousia }\end{array}$ & $\begin{array}{l}\text { Meretrix lusoria }(b) \\
\text { Mactra chinensis }(\mathrm{b}), \\
\text { M. veneriformes (b) }\end{array}$ & & Japan & Sugawara et al. (1961) \\
\hline $\begin{array}{l}\text { Musculista } \\
\text { senhousia }\end{array}$ & Tapes phillipanarum (b) & & Japan & Uchida (1965) \\
\hline $\begin{array}{l}\text { Musculista } \\
\text { senhousia }\end{array}$ & $\begin{array}{l}\text { Protothaca staminea (b). } \\
\text { Chione undatella (b) }\end{array}$ & & San Diego, CA, USA & Crooks (1992) \\
\hline $\begin{array}{l}\text { Musculista } \\
\text { senhousla }\end{array}$ & $\begin{array}{l}\text { scallops, } \\
\text { Xenostrobus pulex (b) }\end{array}$ & Nucula hartvigiana (b) & New Zealand & Willan (1987) \\
\hline $\begin{array}{l}\text { Musculista } \\
\text { senhousia }\end{array}$ & & Polychaetes & $\begin{array}{l}\text { Diversity and density } \\
\text { hıgher in bed; Hong Kong }\end{array}$ & Hutchings \& Wells (1992) \\
\hline $\begin{array}{l}\text { Musculista } \\
\text { senhousia }\end{array}$ & & $\begin{array}{l}\text { Leptochelia dubia ( } \mathrm{t}) \text {, Barleeia } \\
\text { subtenuis }(\mathrm{g}), \mathrm{crustaceans} \\
\text { midge larvae, and other taxa }\end{array}$ & $\begin{array}{l}\text { Density and no. of spp. } \\
\text { typically higher in mats; } \\
\text { San Diego }\end{array}$ & This study \\
\hline Mytilus edulis & & Carcinus maenas (c) & Europe & Thiel \& Dernedde (1994) \\
\hline Mytilus edulis & $\begin{array}{l}\text { sf polychaetes, } \\
\text { ostracods, nematodes, } \\
\text { predatory } \\
\text { platyhelminthes }\end{array}$ & $\begin{array}{l}\text { df polychaetes, oligochaetes, } \\
\text { epibenthic and epiphytic spp.. } \\
\text { grazing platyhelminthes }\end{array}$ & $\begin{array}{l}\text { No. of spp. higher in } \\
\text { bed; density lower in } \\
\text { bed; North Sea }\end{array}$ & Dittmann $(1990)$ \\
\hline Mytilus edulis & $\begin{array}{l}\text { Nepthys incisa (p), } \\
\text { 'non-oligochaetes' }\end{array}$ & Oligochaetes & $\begin{array}{l}\text { Density higher in bedi } \\
\text { New England, USA }\end{array}$ & $\begin{array}{l}\text { Commito (1987), } \\
\text { Commito \& Boncavage (1989) }\end{array}$ \\
\hline $\begin{array}{l}\text { Mytilus } \\
\text { chilensis, } \\
\text { Choromytilus } \\
\text { chorus }\end{array}$ & $\begin{array}{l}\text { Capitellidae (p) } \\
\text { Polydora sp. (p) }\end{array}$ & & $\begin{array}{l}\text { Density, no. of spp., } \\
\text { diversity }\left(H^{\prime}\right) \text { comparable } \\
\text { or lower in bed; Chile }\end{array}$ & $\begin{array}{l}\text { Jaramillo et al. (1992), } \\
\text { Quijón et al. (1996) }\end{array}$ \\
\hline
\end{tabular}




\section{DISCUSSION}

\section{Patterns of abundance and species richness within mussels beds}

In the remnant natural wetland of Mission Bay, mats created by Musculista are often distinctive features that alter the physical environment and composition of biotic communities. Typically, decimeter- to metersized patches of mats appear to facilitate other organisms, as species richness (Figs. $3 \& 6$ ) and density of individuals (Figs. 3, $4 \& 5$ ) are typically higher within mussel mats compared to adjacent no-mat patches. Some of the taxa that appear able to exploit the new habitat provided by Musculista include tanaids, gastropods, amphipods, insect larvae, and polychaetes. Surface-feeding, direct-developing species appear to benefit most from the presence of mussel mats (Fig. 7).

As in Mission Bay, Musculista in other locations has been reported to facilitate organisms (Table 5). The small bivalve Nucula hartvigiana in New Zealand (Willan 1987) and polychaetes in Hong Kong (Hutchings \& Wells 1992) were found in higher abundances within mats than in areas without mussels. The epifaunal mussel Mytilus edulis, when forming beds in soft sediments, can also facilitate infauna such as oligochaetes (Commito 1987), crabs (Thiel \& Dernedde 1994), and other macrofaunal taxa (Dittmann 1990) (Table 5). Negative effects of mussel beds have also been reported. Larger bivalves and eelgrass have been reported to be inhibited by Musculista mats (Sugawara et al. 1961, Uchida 1965, Willan 1987, Reusch \& Williams in press). Polychaetes and other small infauna (Commito 1987, Dittmann 1990, Jaramillo et al. 1992) have been reported in lower densities within beds of other mussel species (Table 5).

The positive effects of mussel mats in soft-sediment habitats resemble the effects of mussel beds on rocky substrates. Despite the ability of hard-substratedwelling mussels to outcompete larger organisms for space (e.g. Paine 1974), mussels beds can provide unique habitat for other, typically smaller, organisms (Suchanek 1985, Seed 1996). Increased abundances and/or diversities within mussel beds have been reported for a variety of mussel species, including Mytilus californianus (Kanter 1980), $M$. edulis and $M$. galloprovincialis (Tsuchiya \& Nishihara 1986, Tsuchiya \& Bellan-Santini 1989, Matsumasa \& Nishihara 1994), Semimytilus algosus (Tokeshi \& Romero 1995), Modiolus modiolus (Brown \& Seed 1977, Witman 1985), Septifer virgatus (Ong Che \& Morton 1992, Seed \& Brotohadikusumo 1994), S. bilocularis (Jackson 1976), and Brachidontes rostratus (Stephenson \& Stephenson 1972, Peake \& Quinn 1993). It has also been found that species outcompeted for primary space by mussels can live epizoically on the mussel shells (Lohse 1993,
Tokeshi \& Romero 1995). Even beds created by zebra mussels Dreissena polymorpha benefit populations of a wide variety of small invertebrates (Dermott 1992, Stewart \& Haynes 1994)

\section{Habitat alteration by mussels}

The above cases of facilitation by mussels are the effects of habitat alteration caused by mussel-induced, architectural changes. Mussel beds provide structurally complex habitats that may alter water flow, ameliorate environmental conditions such as temperature and humidity, accumulate sediments on hard substrates (Suchanek 1985, Seed \& Suchanek 1992), and stabilize sediments on soft substrates (this study). These effects result from the presence of mussel shells themselves ('autogenic engineering'), as well as from binding of sediments and other material by byssal threads ('allogenic engineering'; Jones et al. 1994). In addition, mussels may filter the water column (Kautsky \& Evans 1987, Wilkinson et al. 1996j. This activity by zebra mussels in fresh waters of the eastern U.S. has led to increased light penetration and growth of aquatic macrophytes at depth (Lowe \& Pillsbury 1995).

For Musculista in Mission Bay, habitat alteration produces a variety of inter-related effects. At the broadest level. Musculista is creating physical structure on the tidal flat. The results of the manipulative experiment suggest that simply the presence of structure can facilitate resident biota (Table 4). This may relate to any of a variety of mechanisms, including the alteration of environmental parameters (discussed above), active habitat selection or thigmotactic responses of motile macrofauna such as crustaceans (e.g. Olyslager \& Williams 1993), or refuge from predation afforded by the presence of structure (Witman 1985, Medeiros-Bergen \& Miles 1997). Similar patterns of increased faunal abundances or diversities have been seen with a variety of other species that provide structural complexity, including other mussels (as discussed above), tube-building worms (Haines \& Maurer 1980) and seagrasses (Homziak et al. 1982).

In addition to creating structure, mats of Musculista incorporate a variety of organic and inorganic material (e.g. algal and eelgrass fragments and fine sediments) to which other species may respond. For example, the tanaid Leptochelia dubia is a small crustacean which constructs tubes out of sediment and organic debris. The 3-dimensional matrix created by the mussel mats may offer $L$. dubia both a supply of materials with which to construct their tubes and a structure in which the tubes can be built. In other bays, $L$. dubia is often found associated with physical structures such as green algae on mudflats and fouling growth on pier pilings (Morris et al. 1980). 
Because of the binding of sediments and organic matter, trapping of feces and pseudofeces, and passive deposition of low-density material, Musculista mats also alter sedimentary properties (Morton 1974). In this study, well-developed mats contained more fine sediments and combustible organic matter than nearby areas without mats (Table 1). In Hong Kong, Musculista was observed to convert a sand flat into a mud flat (Morton 1974), and the sediment under dense beds of Musculista can appear black and anoxic (Anonymous 1965, author's pers. obs.). Similar patterns have also been observed in New Zealand (Creese \& Hooker 1996). Other mussels (e.g. Mytilus edulis) can also increase fine sediment and organic matter through biodeposition (Kautsky \& Evans 1987, ten Brinke et al. 1995). On rocky shores, passive deposition and trapping of fine sediments within mussel beds can occur to such an extent that an 'infaunal' component of the fauna has been recognized (Suchanek 1985, Ong Che \& Morton 1992, Tokeshi 1995).

The alteration of organic matter within sediments may serve to increase food resources which may favor surface feeders, as was seen in natural Musculista mats (Fig. 7A, B). However, sedimentary properties alone can not fully explain observed differences within Musculista mats, because even when no differences in sediment properties were evident (July 1994), some differences in the macrofaunal communities existed (e.g. species richness, Fig. 3C). Although increased organic matter within mussel mats might be expected to benefit subsurface as well as surface feeders, there was no increase in density of subsurface feeders (Fig. 7A, B).

One predicted effect of the mussels, related to suspension feeding by Musculista, was the inhibition of organisms with planktonic larvae (Woodin 1976). In this study, however, this inhibition was not observed; densities of species with planktonic larvae were comparable inside and outside mats (Fig. 7C, D). Possible explanations for this result include the lack of actual inhibition of larval settlement or post-settlement migration from no-mat to mat areas. Although densities of species with planktonic larval forms were not inhibited, neither were they greatly facilitated. Directdevelopers were typically much more abundant in mats than in adjacent mat-free sediments (Fig. 7C). Commito (1987) and Commito \& Boncavage (1989) also reported increased abundances of a direct-developer (the oligochaete Tubificoides benedeni) within softsediment beds of the mussel Mytilus edulis.

\section{Habitat alteration by exotics and effects on resident assemblages}

Examination of invasive habitat modifiers permits us to evaluate the mechanisms and time-scales of response of resident species to biogenically altered environmental conditions. For example, in this study, Musculista mats facilitated many small infauna, largely through the construction of physical structure that provided habitat for these species. Resident species appeared to rapidly and repeatedly take advantage of the seasonal appearance and disappearance of the mats on the tidal flat, and significant faunal responses were also seen after just 2 wk in the manipulative experiment. In a broader sense, the resident biota have also responded rapidly to the presence of Musculista in that this species has only been abundant in the intertidal of Mission Bay for less than 3 decades (Crooks 1992).

Although there are relatively few studies on exotic marine species capable of ecosystem alteration, those that exist provide insights into invasion biology. In New England, the introduced periwinkle Littorina littorea is able to alter habitats by bulldozing algae on hard shores and inhibiting the growth and spread of cordgrass Spartina alterniflora on soft substrates (Bertness 1984). Organisms that are able to create structure have facilitory effects similar to those of Musculista. In the U.S. Pacific Northwest, intertidal beds of the exotic eelgrass Zostera japonica have more fine-grained sediments, combustible organic matter, and species than unvegetated sediments (Posey 1988). Within beds of the exotic vascular plant Hydrilla verticilatta in Chesapeake Bay (eastern U.S.), 8 taxa experienced increased abundances (Posey et al. 1993). It is important to remember, however, that this facilitation may be scaledependent (as is the case for Musculista) and that these exotics may have different effects on other organisms This is exemplified by the zebra mussel which, despite its ability to facilitate some small macrofauna, adversely affects other species through smothering and filtration of the water column (Nalepa \& Schloesser 1993, Stewart \& Haynes 1994, Lowe \& Pillsbury 1995). Nonetheless, positive interactions between exotics and resident biota are rarely recognized as a general consequence of a biological invasion.

Habitat modification by exotic species, such as that seen for Musculista, Littorina littorea, and Zostera japonica, is by no means limited to marine systems. Non-native species capable of altering the physical environment are found in many of the world's invaded ecosystems (author unpubl.). Given the potential consequences of these invasions, habitat alteration should be considered a major effect of exotic organisms. Although the continued introduction of habitat-modifying exotics into ecosystems poses serious management and conservation concerns, the further study of the role of these organisms will provide a better understanding of the relationships between individual species, biotic communities, and habitats. 
Appendix 1. List of fauna found during the study. Occurrence is the abundance of the species in the samples, averaged across dates: uncommon is $<1 \operatorname{core}^{-1}\left(0.001 \mathrm{~m}^{2}\right)$, common is $<10 \operatorname{core}^{-1}$, and abundant is $>10 \mathrm{cor}^{-1}$. Mat $>$ no mat represents number of dates (out of 5 ) where the average number in the mat samples was siginificantly greater than the number in the adjacent no-mat samples (approximately $0.5 \mathrm{~m}$ away). In no instance was the number in the no-mat samples significantly greater than the number in the mat samples. Also provided are assigned feeding and larval development modes of the species: Surface = surface-deposit feeders, suspension feeders, and macrophages $_{i}$ Subsurface $=$ subsurface-deposit feeders $_{i}$ Planktonic $=$ planktotrophic and lecithotrophic developers; Direct $=$ direct benthic developers. "Exotic (Cohen \& Carlton 1995); " these taxa were not identified to species and therefore contributed only 1 species to tallied species counts

\begin{tabular}{|c|c|c|c|c|}
\hline Taxon & Occurrence & Mat > no mat & Feeding mode & Larval mode \\
\hline Cnidarians. & Uncommon & & Surface & Unknown \\
\hline Platyhelminthes" & Common & 1 & Unknown & Direct \\
\hline Nemerteans $"$ & Uncommon & 1 & Surface & Unknown \\
\hline \multicolumn{5}{|l|}{ Molluscs } \\
\hline \multicolumn{5}{|l|}{ Bivalves } \\
\hline Musculista senhousla ${ }^{\circ}$ & Common & & Surface & Planktonic \\
\hline Mytilus galloprovincialis & Uncommon & & Surface & Planktonic \\
\hline \multicolumn{5}{|l|}{ Gastropods } \\
\hline Acteocina culcitella & Common & & Subsurface & Planktonic \\
\hline Barleeia subtenuis & Common & 3 & Surface & Direct \\
\hline Caecum californicum & Uncommon & & Surface & Unknown \\
\hline \multicolumn{5}{|l|}{ Annelids } \\
\hline \multicolumn{5}{|l|}{ Polychaetes } \\
\hline Armandia brevis & Uncommon & & Subsurface & Planktonic \\
\hline Capitella sp. & Abundant & 3 & Subsurface & Unknown \\
\hline Eteone californica & Common & & Surface & Planktonic \\
\hline Eteone pacifica & Uncommon & & Surface & Planktonic \\
\hline Exogene cf. lourei & Abundant & 1 & Surface & Direct \\
\hline Fabricinuda limnicola & Common & & Surface & Direct \\
\hline Haploscoloplos elongatus & Uncommon & & Subsurface & Unknown \\
\hline Polydora ligni & Uncommon & & Surface & Planktonic \\
\hline Prionospio (Minuspio) sp. A & Uncommon & & Surface & Unknown \\
\hline Prionospio heterobranchia & Uncommon & & Surface & Planktonic \\
\hline Pseudopolydora paucibranchiata. & Abundant & & Surface & Planktonic \\
\hline Sabellid sp. B & Uncommon & & Surface & Direct \\
\hline Schistomeringos rudolphi & Common & 1 & Surface & Planktonic \\
\hline Streblospio benedicti & Uncommon & & Surface & Planktonic \\
\hline Ampharetid sp. A & Uncommon & & Surface & Unknown \\
\hline Opheliid sp. A & Uncommon & & Unknown & Unknown \\
\hline Syllid sp. A & Uncommon & & Surface & Unknown \\
\hline Lumbrinerid sp. A & Uncommon & & Surface & Unknown \\
\hline Nereid sp. A & Uncommon & & Surface & Unknown \\
\hline Maldanid sp. A & Uncommon & & Subsurface & Unknown \\
\hline Unidentified ${ }^{*}$ & Uncommon & & Unknown & Unknown \\
\hline \multicolumn{5}{|l|}{ Oligochaetes } \\
\hline Limnodriloides barnardi & Abundant & & Subsurface & Direct \\
\hline Paranais littoralis & Uncommon & & Subsurface & Direct \\
\hline Tubificoides brownea & Abundant & & Subsurface & Direct \\
\hline Unidentified ". & Uncommon & & Subsurface & Direct \\
\hline \multicolumn{5}{|l|}{ Arthropods } \\
\hline \multicolumn{5}{|l|}{ Amphipods } \\
\hline Ampithoe sp. & Uncommon & & Surface & Direct \\
\hline Corophium acherusicum ${ }^{\circ}$ & Common & & Surface & Direct \\
\hline Elasmopus bampo & Uncommon & & Surface & Direct \\
\hline Grandidierella japonica. & Common & 1 & Surface & Direct \\
\hline Hyale sp. A & Common & 2 & Surface & Direct \\
\hline Mayerella banksia & Uncommon & 1 & Surface & Direct \\
\hline Podocerus cristatus & Uncommon & & Surface & Direct \\
\hline Pontogenia rostrata & Uncommon & & Surface & Direct \\
\hline Protomedeia sp. & Uncommon & & Surface & Direct \\
\hline Unidentified gammarids". & Uncommon & & Surface & Direct \\
\hline \multicolumn{5}{|l|}{ Tanaids } \\
\hline Leptochelia dubia & Abundant & 4 & Surface & Direct \\
\hline \multicolumn{5}{|l|}{ Cumaceans } \\
\hline Cumacean sp. A & Uncommon & & Surface & Direct \\
\hline \multicolumn{5}{|l|}{ Isopods } \\
\hline Haliophasma geminatum & Uncommon & & Surface & Direct \\
\hline Unidentified & Uncommon & & Surface & Direct \\
\hline \multicolumn{5}{|l|}{ Insects } \\
\hline Chironomid larvae & Common & 3 & Surface & Direct \\
\hline Unidentified Coleoptera A & Uncommon & & Unknown & Unknown \\
\hline Phoronids & & & & \\
\hline Phoronis architecta & Uncommon & & Surface & Planktonic \\
\hline \multicolumn{5}{|l|}{ Echinoderms } \\
\hline Holothuroids & & & & \\
\hline Leptosynapta albicans & Uncommon & & Surface & Direct \\
\hline
\end{tabular}


Acknowledgements. I gratefully acknowledge the assistance of Lisa Levin, Paul Dayton, William Newman, Jim Enright, John Largier, and Dave Woodruff. Their guidance through the course of this resedrch has been immensely valuable. I also thank Luis Ignacio Vilchis, Robin Oleata, Hugh Khim, Augusta Jones, Dean Pasko, Christopher Martin, and Debra Fruetel for their help in the lab and field. Thanks also to Kevin Crooks, Ronald Kneib, and 2 anonymous reviewers for their helpful comments on the manuscript, and to Jana Davis for the illustrations. Portions of this research were funded by the PADI Foundation, the Mildred Mathias Grant of the University of California Natural Reserve System, and the E.W. Scripps Foundation.

\section{LITERATURE CITED}

Anonymous (1965) Report of the survey on protected shellfish fishing ground. Chiba Prefecture Inshore Fishery Experiment Station, Chiba (in Japanese)

Asakura A (1992) Recent introductions of marine benthos into Tokyo Bay (review): process of invasion into an urban ecosystem with discussion on the factors inducing their successful introduction. J Nat Hist Mus Inst, Chiba 2:1-14 (in Japanese with English summary)

Bertness MD (1984) Habitat and community modification by an introduced herbivorous snail. Ecology 65(2):370-381

Brenchley GA, Carlton JT (1983) Competitive displacement of native mud snails by introduced periwinkles in the New England intertidal zone. Biol Bull Mar Biol Lab Woods Hole 165:543-558

Brown RA, Seed R (1977) Modiolus modiolus (L.) - an autecological study. In: Keegan NF, O'Ceidigh P, Boaden PJS (eds) Biology of benthic organisms. Pergamon Press, Oxford. p 93-100

Carlton JT (1979) History, biogeography, and ecology of the introduced marine and estuarine invertebrates of the Pacific coast of North America. PhD Dissertation, University of California, Davis

Carlton JT (1989) Man's role in changing the face of the ocean: biological invasions and implications for conservation of near-shore environment. Conserv Biol 3(3):265-273

Carlton JT, Geller J (1993) Ecological roulette: the global transport and invasion of non-indigenous marine organisms. Science 261:78-82

Cohen AN, Carlton J (1995) Non-indigenous aquatic species in a United States estuary: a case study of the biological invasions of the San Francisco Bay and Delta. United States Fish and Wildlife Service Report no. PB96-166525, Washington, DC

Commito JA (1987) Adult-larval interactions: predictions, mussels, and cocoons. Estuar Coast Shelf Sci 25:599-606

Commito JA, Boncavage EM (1989) Suspension-feeders and coexisting infauna: an enhancement counterexample. J Exp Mar Biol Ecol 125:33-42

Creese RG. Hooker SH (1996) The ecology and environmental impact of the Asian date mussel Musculista senhousia. Aukland Uniservices Limited, Auckland

Crooks JA (1992) The ecology of the introduced bivalve, Musculista senhousia, in Mission Bay, San Diego. MSc thesis, San Diego State University

Crooks JA (1996) The population ecology of an exotic mussel, Musculista senhousia, in a southern California bay. Estuaries 19(1):42-50

D'Antonio CM, Dudley TL (1995) Biological invasions as agents of change on islands versus mainlands. In: Vitousek P, Loope LL, Adsersen $\mathrm{H}$ (eds) Islands. Ecological studies,
Vol 115. Springer-Veriag, Berlın, p 103-121

Dermott R (1992) Benthic communty associated with zebra mussel colonies. J Shellfish Res 11(1):223

Dittmann S (1990) Mussel beds-ammensalism or amelioration for intertidal fauna. Helgol Meeresunters 44:335-352

Fauchald K, Jumars PA (1979) The diet of worms: a study of polychaete feeding guilds. Oceanogr Mar Biol Annu Rev $17: 193-284$

Furota $T$ (1996a) Life-cycle studies of the introduced spider crab Pyromaia tuberculata (Lockington) (Brachyura: Majidae). I. Egg and larval stages. J Crustac Biol 16(1):71-76

Furota T (1996b) Life-cycle studies of the introduced spider crab Pyromaia tuberculata (Lockington) (Brachyura: Majidae). II. Crab stage and reproduction. J Crustac Biol 16(1): $77-91$

Grosholz ED, Ruiz GM (1995) Spread and potential impact of the recently introduced European green crab, Carcinus maenas, in central California. Mar Biol 122:239-247

Haines JL, Maurer D (1980) Quantitative faunal associates with the serpulid polychaete Hydroides dianthus. Mar Biol $56: 43-47$

Hicks DW (1993) Invasion of the south Texas coast by the edible brown mussel, Perna perna (Linnaeus, 1758). Veliger 36(1):92-94

Hoenselaar HJ, Hoenselaar J (1989) Musculista senhousia (Benson in Cantor, 1842) in the Western Mediterranean (Bivalvia, Mytilidae). Basteria 53:73-76

Homziak J, Fonseca MS, Kenworthy WJ (1982) Macrobenthic community structure in a transplanted eelgrass (Zostera marina) meadow. Mar Ecol Prog Ser 9:211-221

Hurlbert SH (1971) The nonconcept of species diversity: a critique and alternative parameters. Ecology 52(4):577-586

Hutchings PA, Wells FE (1992) An analysis of the marine invertebrate community at Hoi Ha Wan, Hong Kong. In: Morton B (ed) The marine flora and fauna of Hong Kong and Southern China III. Hong Kong University Press, Hong Kong, p 851-864

Jackson LF (1976) Aspects of the intertidal ecology of the east coast of South Africa. South African Association for Marine Biological Research. Oceanogr Res Inst Invest Rep $46: 1-72$

Jaramillo E, Bertrán C, Bravo A (1992) Community structure of the subtidal macroinfauna in an estuarine mussel bed in southen Chile. PSZN I: Mar Ecol 13(4):317-331

Jones CG, Lawton JH, Chachak M (1994) Organisms as ecosystem engineers. Oikos 689:373-386

Jones CG, Lawton JH, Chachak M (1997) Positive and negative effects of organisms as physical ecosystem engineers. Ecology 78(7):1946-1957

Kanter RG (1980) Biogeographic patterns in mussel community distribution from the southern California Bight. In: Power DM (ed) The Californa islands. Proceedings of a multidisciplinary symposium. Santa Barbara Museum of Natural History, Santa Barbara, CA, p 341-355

Kautsky N, Evans S (1987) Role of biodeposition by Mytilus edulis in the circulation of matter and nutrients in a Baltic coastal ecosystem. Mar Ecol Prog Ser 38:201-21.2

Kincaid T (1947) The acclimatization of marine animals in Pacific northwest waters. Minutes Conchol Club Southern California 72:1-3

Krebs CJ (1989) Ecological methodology. Harper Collins Publishers, New York

Lawton JH (1994) What do species do in ecosystems? Oikos $71: 367-374$

Lazzari G (1994) Report on the presence of exotic Mediterranean species in the brackish Ravenna Lagoon. Boll Malacol 30:195-202 
Levin LA (1983) Drift tube studies of bay-ocean water exchange and implications for larval dispersal. Estuaries $6(4): 364-371$

Lohse D (1993) The importance of secondary substratum in a rocky intertidal community. J Exp Mar Biol Ecol 166:1-17

Lowe RL, Pillsbury RW (1995) Shifts in benthic algal community structure and function following the appearance of zebra mussels (Dreissena polymorpha) in Saginaw Bay, Lake Huron. J Great Lakes Res 21(4):558-566

MacDonald KB (1969) Quantitative studies of salt marsh mollusc faunas from the North American Pacific coast. Ecol Monogr 39(1):33-59

Matsumasa M, Nishihara M (1994) Habitat structure provided by Mytilus edulis and the modification by sessle invertebrates. Bull Mar Biol Stn Asamushi 19(2):51-63

Mead R (1988) The design of experiments. Cambridge University Press, Cambridge

Medeiros-Bergen DE, Miles E (1997) Recruitment in the holothurian Cucumaria frondosa in the Gulf of Maine. Invertebr Reprod Dev 31:123-133

Morris RH, Abbott DP, Haderlie EC (1980) Intertidal invertebrates of California. Stanford University Press, Stanford, CA

Morton B (1974) Some aspects of the biology, population dynamics, and functional morphology of Musculista senhausia Benson (Bivalvia, Mytilidae). Pac Sci 28:19-33

Nalepa TF, Schloesser SW (1993) Zebra mussels. Biology, impacts, and control. Lewis Publishers, Boca Raton, FL

Olyslager NJ, Williams DD (1993) Microhabitat selection by the lotic amphipod Gammarus pseudolimnaeus Bousfield: mechanisms for evaluating local substrate and current suitability. Can J Zool 71(12):2401-2409

Ong Che RG, Morton B (1992) Structure and seasonal variations in abundance of the macro-invertebrate community associated with Septifer virgatus (Bivalvia: Mytilidae) at Cape D'Aguilar, Hong Kong. Asian Mar Biol:217-233

Paine RT (1974) Intertidal community structure: experimental studies on the relationship between a dominant competitor and its principal predator. Oecologia 15:93-120

Peake J, Quinn GP (1993) Temporal variation in species-area curves in clumps of an intertidal mussel. Ecography 16: $269-277$

Posey MH (1988) Community changes associated with the spread of an introduced seagrass, Zostera japonica. Ecology 69(4):974-983

Posey MH, Wigand C, Stevenson JC (1993) Effects of an introduced aquatic plant, Hydrilla verticillata, on benthic communities in the Upper Chesapeake Bay. Estuar Coast Shelf Sci 37:539-555

Quijón P, Jaramillo E, Pino M (1996) Macroinfaunal assemblages associated with mussel and clam beds in an estuary in southern Chile. Estuaries 19(1):62-74

Race MS (1982) Competitive displacement and predation between introduced and native mud snails. Oecologia 54: $337-347$

Reusch TBH, Williams S (in press) Variable response of native Zostera marina to a non-indigenous bivalve Musculista senhousia. Oecologia

Safriel UN, Sasson-Frostig Z (1988) Can colonizing mussel outcompete indigenous mussel? J Exp Mar Biol Ecol 117 : 211-226

Seed R (1992) Systematic evolution and distribution of mussels belonging to the genus Mytilus: an overview. Am Malacol Bull 9(2):123-137

Seed R (1996) Patterns of biodiversity in the macro-invertebrate fauna associated with mussel patches on rocky shores. J Mar Biol Assoc UK 76:203-210
Seed R, Brotohadikusumo NA (1994) Spatial variation in the molluscan fauna associated with Septifer virgatus (Bivalvia: Mytilidae) at Cape D'Aguilar, Hong Kong. In: Morton $B$ (ed) The malacofauna of Hong Kong and southern China III. Hong Kong University Press, Hong Kong, p $427-444$

Seed R, Suchanek TH (1992) Population and community ecology of Mytilus. In: Gosling $E$ (ed) The mussel Mytilus: ecology, physiology, genetics, and culture. Elsevier, Amsterdam, p 87-169

Simberloff D (1981) Community effects of introduced species. In: Niteckı MNH (ed) Biotic crises in ecological and evolutionary time. Academic Press, New York, p 53-83

Stephenson TA, Stephenson A (1972) Life between tidemarks on rocky shores. WH Freeman and Co, San Francisco

Stewart TW, Haynes JM (1994) Benthic macroinvertebrate communities of southwestern Lake Ontario following invasion of Dreissena. J Great Lakes Res 20(2):479-493

Stewart-Oaten A (1995) Rules and judgements in statistics: three examples. Ecology 76(6):2001-2009

Suchanek TH (1985) Mussels and their role in structuring rocky shore communities. In: Moore $P G$, Seed $R$ (eds) The ecology of rocky coasts. Hodder and Stoughton, London, p $70-96$

Sugawara K, Ebihara T, lhii T, Aoki K, Uchida A (1961) Outbreak of a mussel Brachidontes senhousia in Urayasu shellfish rearing ground. Rep Chiba Prefecture Inner-Bay Fish Exp Stn 3:83-92 (in Japanese)

Tanaka M, Kikuchi $T$ (1978) Ecological studies on benthic macrofauna in Tomoe Cove, Amakusa II. Production of Musculista senhousia (Bivalvia, Mytilidae). Publ Amakusa Mar Biol Lab 4\{3\}:215-233

ten Brinke WBM, Augustinus PGEF, Berger GW (1995) Fine-grained sediment deposition on mussel beds in the Oosterschelde (The Netherlands), determined from echosoundings, radio-isotopes, and biodeposition field experiments. Estuar Coast Shelf Sci 40:195-217

Thiel M, Dernedde T (1994) Recruitment of shore crabs Carcinus maenas on tidal flats: mussel clumps as an important refuge for juveniles. Helgol Meeresunters 48:321-332

Tokeshi M (1995) Polychaete abundance and dispersion patterns in mussel beds: a non-trivial 'infaunal' assemblage on a Pacific South American rocky shore. Mar Ecol Prog Ser 125:137-147

Tokeshi M, Romero L (1995) Filling a gap: dynamics of space occupancy on a mussel-dominated subtropical rocky shore. Mar Ecol Prog Ser 119:167-176

Tsuchiya M, Bellan-Santini D (1989) Vertical distribution of shallow rocky shore organisms and community structure of mussel beds (Mytilus galloprovincialis) along the coast of Marseille, France. Mesogée 49:91-110

Tsuchiya M, Nishihara M (1986) Islands of Mytilus as a habitat for small intertidal animals: effect of Mytilus age structure on the age structure and species composition of the associated fauna and community organization. Mar Ecol Prog Ser 31:171-178

Uchida A (1965) Growth of a mussel Musculista senhousia and the influence of Musculista senhousia on the clam Tapes philippinarum. Rep Chiba Prefecture Inner Bay Fish Exp Stn 7:69-78 (in Japanese)

Vitousek PM (1990) Biological invasions and ecosystem processes: towards an integration of population biology and ecosystem studies. Oikos 57:7-13

Wilkinson SB, Zheng $W$, Allen JR, Felding NJ, Wanstall VC, Russel G. Hawkins SJ (1996) Water quality improvements in Liverpool docks: the role of filter feeders in algal and nutrient dynamics. PSZN I: Mar Ecol 17(1-3):197-211 
Willan RC (1987) The mussel Musculista senhousia in Australasia; another aggressive alien highlights the need for quarantine at ports. Bull Mar Sci 41(2):475-489

Williamson M (1996) Blological invasions. Chapman and Hall, London

Wilson WH Jr (1991) Sexual reproductive modes in polychaetes.

Editorial responsibility: Ron Kneib (Contributing Editor), Sapelo Island, Georgia, USA
Classification and diversity. Bull Mar Sci 48(2):500-516 Witman JD (1985) Refuges, biological disturbance, and rocky intertidal community structure in New England. Ecol Monogr 55(4):421-445

Woodin SA (1976) Adult-larval interactions in dense infaunal assemblages: patterns of abundance. J Mar Res 34(1):25-41

Submitted: July 12, 1997; Accepted: November 7, 1997 Proofs received from author(s): January 9, 1998 